\title{
Accordion effect in right coronary artery mimicking dissection
}

\section{Sağ koroner arterde diseksiyonu taklit eden akordiyon efekti}

\author{
Adnan Kaya ${ }^{1}$, *Mustafa Adem Tatlısu ${ }^{1}$, Dilaver Öz $z^{1}$, Mehmet Eren ${ }^{1}$ \\ ${ }^{1}$ Department of Cardiology, Dr. Siyami Ersek Cardiovascular and Thoracic Surgery Center, İstanbul, Turkey \\ Corresponding author: Dr. Siyami Ersek Kardiyovasküler ve Göğüs Cerrahisi Merkezi, TR-34668 İstanbul, Turkey \\ Received/Accepted: February 13, 2014/April 17, 2015 \\ Conflict of interest: There is not a conflict of interest.
}

\section{SUMMARY}

Accordion or concertina effect is defined as a pseudolesion of tortuous arteries which confused with false dissection, spasm, thrombus and embolus appearence and that gives great concerns to the operator occurs due to straightening and shortening of the vessels with stiff guide wires during the intervention. We present a case of accordion effect in proximal segment of right coronary artery in 51-year-old patient with ST-segment elevation myocardial infarction. Coronary artery dissection during percutaneous transluminal coronary angioplasty is commonly seen in clinical practice. This case is a brief report on concertina effect. We must keep in mind concertina effect before proceeding with a coronary intervention as an interventional cardiologist.

Keywords: ST-segment elevation myocardial infarction, right coronary artery, accordion effect, pseudocomplication

\section{ÖZET}

\begin{abstract}
Akordiyon veya konçertina etkisi tortiyoze arterlerin bir psödolezyonu olup, yalancı diseksiyon, spazm, trombüs ve emboli görünümü ile karışabilir ve girişim sırasında sert kılavuz tellerle damarların kısaltılıp doğrultulması nedeniyle işlemcide büyük bir endişe uyandırır. Bu makalede ST segment elevasyonlu myokard infarktüsü olup; sağ koroner arterin proximal segmentinde akordiyon etkisi bulunan 51 yaşında bir olgu sunulmuştur. Klinik uygulamada perkütan transluminal koroner anjioplasti esnasında koroner arter disseksiyonu görülmesi yaygındır.Bu vaka konçertina etkisi ile ilgili kısa bir bildiridir. Girişimsel kardiyologların koroner girişimler sırasında konçertina etkisini akıllarında bulundurmaları gerekmektedir.

Anahtar sözcükler: ST segment elevasyonlu myokard enfarktüsü, sağ koroner arter, akordiyon etkisi, psödokomplikasyon
\end{abstract}

\section{INTRODUCTION}

Accordion effect of coronary artery is described firstly by Grewe et al. in an internal mammary graft during percutaneous coronary intervention (PCI) to native left anterior descending (LAD) coronary artery ${ }^{1}$. Concertina or accordion effect is an appearance of artifactual or pseudolesions during the course of PCI in tortuous vessels ${ }^{1,} 2, \quad 3$. The possible mechanism suggested for accordion effect is straightening and shortening of tortuous artery by the stiff wire ended with invagination which showed up as a "stair step deformity" with contrast dye. Sometimes it is difficult to distinguish accordion effect from complications. When accordion effect misdiagnosed as a possible major complication of intervention like dissection, thrombus, spasm and embolisation of vessel than the complication follows by postdilatation of the accordion effect segment with balloon and stent placement. Here we describe a an accordion effect of totally occluded tortuous right coronary artery (RCA) due to acute inferior wall myocardial infarction. To our knowledge this is the 
first time the accordion effect is described in a ST-segment elevation myocardial infarction.

\section{CASE REPORT}

A 51-year-old male patient presented to our emergency department with angina pectoris started two hours ago. Physical examination showed no abnormal findings. The 12-lead electrocardiogram showed STsegment elevation in leads II, III, aVF. The initial troponin I was found to be positive with $0.97 \mathrm{ng} / \mathrm{dL}(0-0.006)$ and CKMB was found to be $5.6 \mathrm{ng} / \mathrm{dL}(0-4.9 \mathrm{ng} / \mathrm{mL})$. Transthoracic echocardiography revealed inferior and lateral wall hypokinesis of left ventricle with ejection fraction 45\%. 300 mg chewable acetylsalicylic acid and 600 mg clopidogrel were administered to the patient and then he was taken to the coronary angiography laboratory for primary PCI. Primary PCI was performed with standard 6F 4 Judkins (Cordis, Johnson\&Johnson, Miami, FL, USA) catheters via right femoral approach. Coronary angigogram revealed a normal LAD, left circumflex artery and total occlusion of RCA starting from the mid segment (Figure 1). The proximal segment of RCA was extremely tortuous and no sign of atherosclerosis was observed. Collateral flows from left coronary system filled the distal RCA partially. Revascularization of RCA was planned and RCA was intubated with 6F 4 Judkins (Cordis, Johnson\&Johnson, Miami, FL, USA) right guiding catheter. A $0.0014 \mathrm{soft}$ guide wire was advanced across the stenosis and balloon dilatation was performed with a $2 \times 10 \mathrm{~mm}$ balloon (Biotronic Medical) at 12 atm. While pushing forward and inflating the balloon in the middle segment of the vessel, a "tire-buchon" like figure was observed from ostium to the mid segment of the vessel in contrast filled views. Dissection and thrombus formation were taught at the first sight. Multiple predilatations were done without fear because we have already passed the mid segment of the vessel and we were sure that the wire was not subintimal at the ostium. It was just after the pull balloon back in to the catheter that distal blood flow of RCA regained and the angina of the patient vanished. Eighty percent long residual lesion was visualized from right ventricular ramus to proximal site of distal RCA. Finally deployment of a $3.5 \times 28 \mathrm{~mm}$ bare metal stent (Ephesus) was performed to the mid segment of the vessel. After having a good result of distal blood flow we concentrated on the hazy lesion of ostium which strongly suggest complicated lesion of dissection, spasm and thrombus (Figure 2). To rule out coronary spasm intracoronary nitroglycerin was administered and the guiding catheter pulled back to wipe out spasm effect of vessel. After nitroglycerin administration and pulling back the catheter no changes were seen and here the effect of concertina in other words accordion effect was thought. Reducing vessel straightening and shortening force by careful withdrawn of guide wire to the proximal segment of concertina resolved this entity. Luckily taking of the guide wire totally from the vessel ended with regain of initial architecture of the vessel. The final outcome was great (Figure 3). The patient was followed four days in hospital and the peak achieved troponin levels was 22.37 $\mathrm{ng} / \mathrm{dL}$. During five years follow-up period no symptoms of stable or unstable angina was recorded. The control angiogram which was done five years later showed normal looking vessel. 


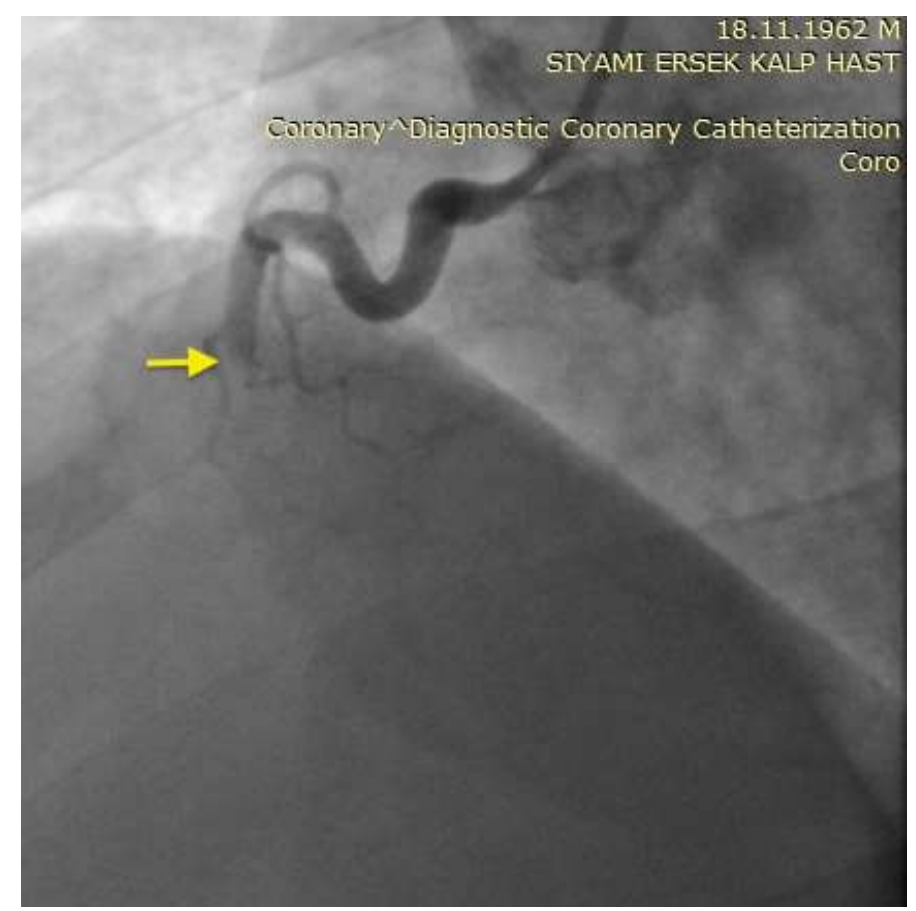

Figure 1: Totally occluded right coronary artery with absent flow.

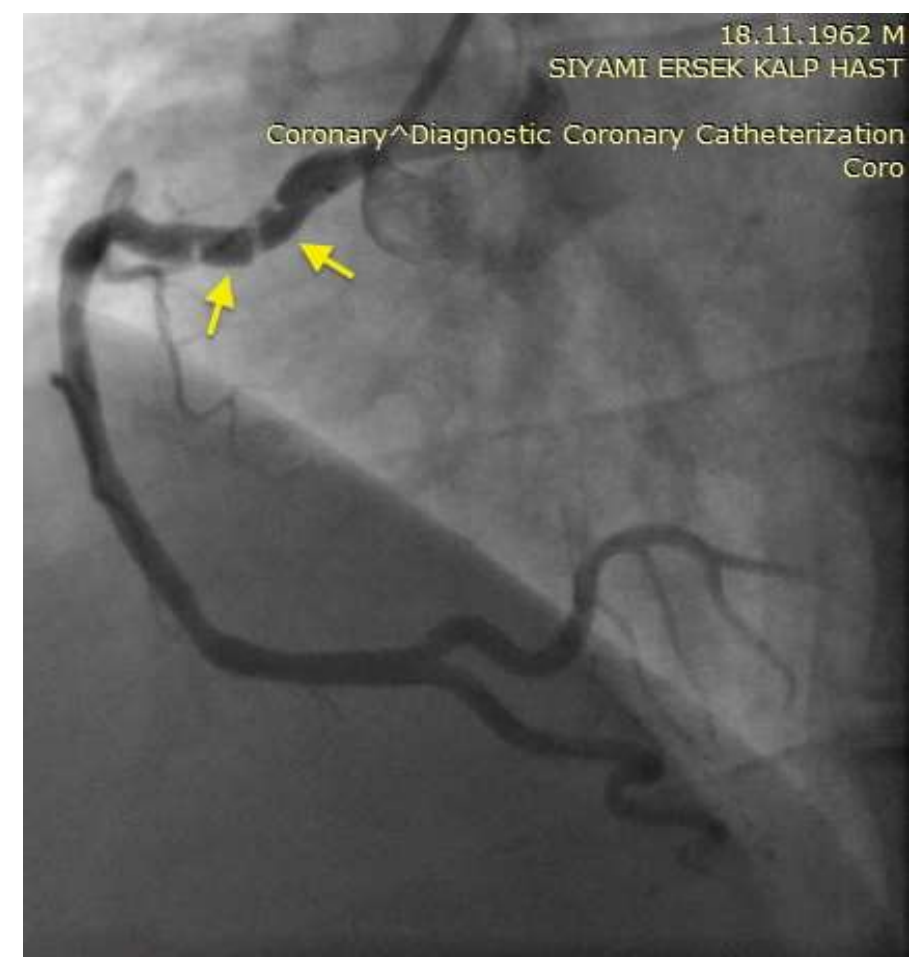

Figure 2: Accordion effect in right coronary artery after stent deployment. 


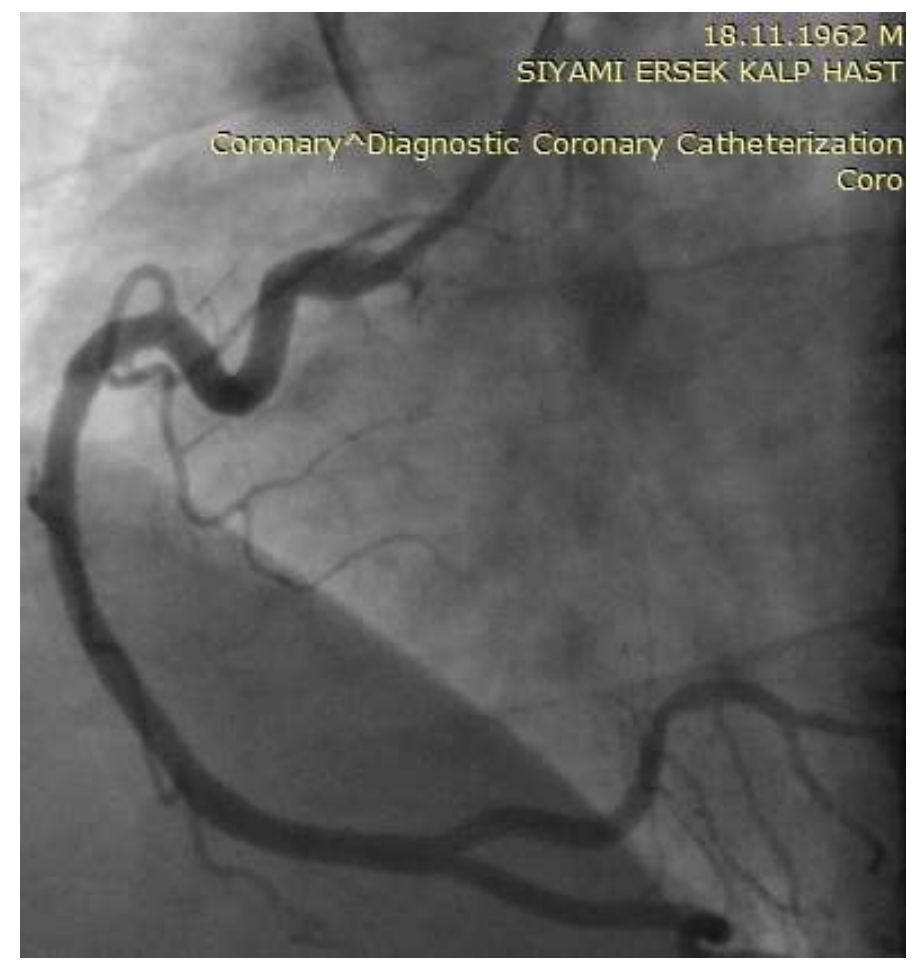

Figure 3: Resolution of the accordion effect.

\section{DISCUSSION}

Coronary blood occlusion during PCI as a complication breaks the operator in a sweat and it is life threatening for the patient. The causes of a true occlusion are dissection of intimal layer of the vessel, thrombus formation, diffuse coronary spasm and embolisation of a thrombus from proximal side of the vessel to distal. Concertina in other words accordion effect is a pseudocomplication of PCI that mimics above cited real complications. The basic mechanism for the appearance of these pseudolesions is the straightening of a tortuous coronary artery along its luminal axis by relatively stiff intracoronary equipment, usually the guide wire, running down its length ${ }^{2}$ 4-6. Straightening the tortuous vessels with stiff guide wires makes it easy to pass the lesion with balloon and to dispose the stent. Entrapment of distal end of the wire with balloon or the lesion and entrapment of proximal side of the wire with intubation of guiding catheter makes the wire entrapped between two sides shorter than the vessel. So unduly vessel tissue invaginates.

After first definition of concertina effect by Grewe et al. in an internal mammary graft, most case reports describe this phenomenon in right coronary angioplasty ${ }^{1}$. It has also been described in left main coronary artery angioplasty ${ }^{7}$, carotid artery angioplasty ${ }^{8}$ and iliac artery angioplasty ${ }^{9}$. The incidence of concertina is about $0.4 \%^{3}$. Confusing concertina with coronary spasm, dissection or thrombus ends with predilatation of non diseased segment of vessel, stent placement or both which turn from a pseudocomplication to a complication. Intracoronary nitrates or calcium channel blockers resolve the vasospasm but not concertina.

The recommended routine for these cases are removal of all intracoronary material including the guide wire and the balloon in to the guiding catheter to facilitate the vessel to reconform to its normal curvature with consequent disappearance of the pseudolesions ${ }^{3}$. For not to skip a dissection Chalet et al. proposed that the guide wire could be cautiously withdrawn up to a point where the floppy segment lies equally on either side of the pseudolesion allowing the vessel to reconform to its normal shape and still retain contact with the distal tip of the wire lying beyond the lesion ${ }^{10}$. Another suggestion from Goel et $\mathrm{al}^{11}$, is leaving the balloon distal to the 
concertina segment with an OTW (Over The Wire) system without guide wire help resolving of concertina and easy use of guide wire exchange beyond the lesion in case $^{11}$.

Concertina effect is not reported before in acute ST-segment elevation myocardial infarction (STEMI). In our case we present management of concertina effect that has been seen in a 51-year-old male with an acute STEMI. As mentioned before tortuous vessels decrease the success probability of the intervention. We were concerned with this pseudocomplication since urgent revascularization has to be restored. Pulling back the wire where just concertina ends regressed it and in final view favorable revascularization achieved.

In conclusion; concertina effect in tortuous vessels can be misdiagnosed although it is not common entity. In case misdiagnose complicated intervention waiting the interventionist as predilatation of normal vessel and stent deployment to normal segment of the vessel. It is important to keep in mind concertina effect not to convert a pseudocomplication to a complication.

\section{REFERENCES}

1. Grewe K, Presti CF, Perez JA. Torsion of an internal mammary graft during percutaneous transluminal coronary angioplasty: a case report. Cathet Cardiovasc Diagn 1990; 19: 195-7.

2. Deligonul U, Tatineni S, Johnson R, Kern MJ. Accordion right coronary artery: An unusual complication of PTCA guidewire entrapment. Cathet Cardiovasc Diagn 1991; 23: 111-3.

3. Rauh RA, Ninneman RW, Joseph D, Gupta VK, Senior DG, Miller WP. Accordion effect in tortuous right coronary arteries during percutaneous transluminal coronary angioplasty. Cathet Cardiovasc Diagn 1991; 23: 10710.

4. Doshi S, Shiu MF. Coronary Pseudolesions induced in the left anterior descending and right coronary artery by the angioplasty guidewire. Int J Cardiol 1999; 68: $337-42$.

5. Blankenship JC. Right coronary artery pseudotransection due to mechanical straightening during coronary angioplasty. Cathet Cardiovasc Diagn 1995; 36: 43-5.

6. Hays JT, Stein B, Raizner AE. The crumpled coronary: an enigma of arteriographic pseudopathology and its potential for misinterpretation. Cathet Cardiovasc Diagn 1994; 31: 293 300.

7. Alvarez JA, Leiva G, Manavella B, Cosentino JJ. Left main crumpling during left anterior descending angioplasty: Hitherto unreported location for the "accordion effect". Catheter Cardiovasc Interv 2001; 52: 363-7.

8. Tsutsumi M, Kazekawa K, Onizuka M, Aikawa H, Iko M, Kodama T, Nii K, Matsubara S, Etou H, Tanaka A. Accordion effect during carotid artery stenting: report of two cases and review of the literature. Neuroradiology 2007; 49: 567-70.

9. Dawson DL, Hellinger JC, Terramani TT, Najibi S, Martin LG, Lumsden LB. Iliac Artery Kinking with Endovascular Therapies: Technical Considerations. J Vasc Interv Radiol 2002; 13: 729-33.

10. Chalet Y, Chevalier B, El Hadad S, Guyon P, Lancelin B. "Pseudo narrowing"during right coronary angioplasty: how to diagnose correctly without withdrawing the guidewire. Cathet Cardiovasc Diagn 1994; 31: 37-40.

11. Goel PK, Agarwal A, Kapoor A. Concertina" Effect during Angioplasty of Tortuous Right and Left Coronary Arteries and Importance of Using Over-theWire System: A Case Report. Indian Heart J 2001; 53: 87-90. 